\title{
Commentary \\ Private Capital to Improve Nature-Based Solutions for Coastal Protection: Time for a Boost
}

\author{
Angelique Brathwaite ${ }^{1,2,3, *}$, Nicolas Pascal ${ }^{1,2,3}$ and Eric Clua ${ }^{1,2,3}$ (D) \\ 1 Blue Finance ECRE (Economics for Coral Reef Ecosystems), Foster Hall St. John, Bridgetown 20002, Barbados; \\ npascal@blue-finance.org (N.P.); eric.clua@univ-perp.fr (E.C.) \\ 2 CRIOBE-USR 3278, PSL Université Paris: EPHE-CNRS-UPVD, 75006 Paris, France \\ 3 Laboratoire d'Excellence CORAIL, Université de Perpignan, 66860 Perpignan, France \\ * Correspondence: abrathwaite@blue-finance.org; Tel.: +33-673-276-854
}

Citation: Brathwaite, A.; Pascal, N.; Clua, E. Private Capital to Improve Nature-Based Solutions for Coastal Protection: Time for a Boost. Oceans 2022, 3, 60-71. https://doi.org/ 10.3390 /oceans 3010006

Academic Editor: Fleur C. van Duyl

Received: 24 September 2021

Accepted: 8 February 2022

Published: 24 February 2022

Publisher's Note: MDPI stays neutral with regard to jurisdictional claims in published maps and institutional affiliations.

Copyright: (C) 2022 by the authors. Licensee MDPI, Basel, Switzerland. This article is an open access article distributed under the terms and conditions of the Creative Commons Attribution (CC BY) license (https:// creativecommons.org/licenses/by/ $4.0 /)$.

\begin{abstract}
Coastal protection, an important coral reef ecosystem service, is threatened by increasing coral mortality, exacerbated by global climate change. Nature-based solutions in the form of coral restoration, while not perfect, can assist in rebuilding reef structure and improving the flow of the service for some sites. With a financing gap existing between what is required for conservation and what is being accessed, private investors should be playing a larger role in such restoration activities. Especially so as coastal hoteliers in particular, benefit from stable beaches and also have additional income generating potential with healthy reefs. Blended finance solutions in particular, are especially suited to restoration that incorporates substrate addition, while payments for ecosystem services are more suited to coral gardening. Conservation and finance practitioners must engage further and understand each other's worlds, in order for these private sources to be effectively sourced and utilized.
\end{abstract}

Keywords: coastal protection; reef restoration; financing mechanisms; nature-based solutions

\section{Introduction}

Coastal protection against beach erosion, is a complex and highly important service, especially for small island developing states (SIDS) with their small land masses, high coastal populations and dependence on coastal tourism [1-3] This ability of coral reefs to attenuate wave energy, as well as to supply and trap sand, allows for reduced flooding and erosion of beaches, protecting coasts and saving lives [4-6]. Coral reefs, while not solely responsible for provision of this ecosystem service [7], can play major roles in providing it [8-10]. Healthy reefs with high coral cover are reported to result in greater wave attenuation and protection for beaches $[7,11,12]$ and their efficacy is reduced with coral deterioration $[13,14]$.

Coral health is declining on a global scale and impacting the ability of reefs to provide a range of ecosystem services [15-17], including coastal protection. There is an increasingly important need to protect and rebuild coral reefs, especially in a time of a changing climate, where this ecosystem is among the most vulnerable [18]. Protecting and rebuilding coral reefs simultaneously reduces risk from global climate change (GCC) impacts, while buttressing economies of coastal nations [19-21].

Solutions do exist for minimizing coastal erosion in the form of built or gray infrastructure. When well designed, breakwaters, for example, can work very efficiently at reducing beach erosion $[22,23]$ however there is no added benefit to the reef that originally provided the service. In addition, such hard infrastructure cannot grow to maintain levels with expected sea level rise (SLR) [24,25]. It seems prudent, therefore, to take steps to improve the condition of coral reefs, as one means of aiding beach protection, and these management measures must be supported by strong investment [26]. 


\section{The Need for Alternative Financing Sources for Conservation}

Globally, while public expenditure on biodiversity averages \$USD6.1 billion per annum, only $4 \%$ of this is directed towards marine biodiversity [27]. Traditional sources, such as governments and philanthropy, are required for conservation but are inadequate [28]. New financing means must be found quickly given the small window of opportunity, reported to be less than 50 years, for both mitigation against stressors and adaptation to a changing climate [26]. With this timeframe, it is imperative that effective action is taken now. Involving the private sector, whose businesses rely on healthy reef systems for a variety of ecosystem services, makes sense. Coastal hoteliers in particular, should play a major role in financing interventions for coastal protection, as they are among the primary beneficiaries of coastal protection, with much to lose from eroding beaches.

For there to be an uptake in private investment for the ecosystem service of coastal protection provided by coral reefs, the service must first be quantified and economically valued, which will vary by site. Methods, both high [21,29] and low tech [30] exist for calculating value, often in terms of avoided damages and replacement costs [8]. Valuation can be used for a variety of reasons, and in this case, advocacy to convince stakeholders of the monetary significance of coastal protection and the need to improve reef health is valid [31]. Protecting beaches is expensive, with the United States of America spending USD $\$ 1.8$ billion on the effort [21], followed by Cuba's USD $\$ 400$ million spend [29] and over USD \$24 million spent by the Government of Barbados in tackling eroding beaches during 2002-2010 [32]. It is further projected to cost coastal cities (annually) around USD $\$ 1$ trillion, to avoid "unacceptable losses" by 2050 [33] and coastal insurers have been reported to have paid out (globally) more than USD $\$ 300$ billion in one decade [8].

\section{Provision of Coastal Protection and Factors That Impact the Service}

Coral reefs provide the coastal protection service by dissipating wave energy, which occurs first as waves break on the shallowest section of the reef $[4,34,35]$ and is further enhanced by friction as the bottom of the wave moves along the sea floor. Then, in order for the service to be maintained, growth via the deposition of calcium carbonate is required to keep the appropriate distance with the sea surface.

SIDS are highly vulnerable to GCC, with SLR of particular importance to the provision of coastal protection [36]. Reef building corals must remain within the photic zone for vertical reef growth to occur and sea levels exert great control on this process, as corals will maintain their growth rates to keep up with rising seas [37]. However, rapidly increasing sea levels-especially when combined with large mortality events, for example from coral bleaching and disease-can result in reefs giving up and drowning [38]. The impact of SLR on coral reefs is site specific and heavily influenced by reef bathymetry and coral species [39]. However, the probability of sea levels rising by $1 \mathrm{~m}$ with an increase of $1.5^{\circ} \mathrm{C}$ by 2100 is high. Without interventions, this could result in a $90 \%$ loss of coral reefs [40]. Beneath this threshold, reefs are not expected to keep up with rising seas, and many regional reefs already exhibit coral cover below this [41].

Coral reef ecosystems, under normal conditions, have the ability to recover naturally [42], however they are reported to require at least 10 years free from major disturbances for the recovery of short lived species and much longer for others [43-45]. Recovery is stymied by an almost continuous onslaught of impacts, exacerbated by lessening natural recruitment and reduced times between catastrophic events [46]. Under such conditions, natural recovery to pre-impact conditions is unlikely $[47,48]$ and human intervention is required.

\section{Active Management for Coastal Protection}

Management should be aimed at achieving no net loss of biodiversity along the mitigation hierarchy: avoid, mitigate, restore, offset, compensate [49]. In many cases, avoidance of stressors is impossible. Mitigation, which is aimed at reducing human pressure, also known as passive management, has dominated marine conservation [50-52]. However, 
these interventions (e.g., actions carried out by marine protected areas-enforcement etc.) have been largely unsuccessful [53,54], and while necessary, have failed to significantly improve reef health $[55,56]$. Many questions remain about the management of human pressures [57], however it seems evident that simply eliminating stressors is inadequate [58]. Restoration, the next tier in the hierarchy, is a form of active management, where humans intervene to directly assist in improving reef condition [59]. Incorporating active alongside passive management interventions has been recommended for increased chances of reef recovery $[12,60,61]$.

Coral restoration is a nature-based solution (NbS) [62] that seeks to rebuild reef structure, which is key to restoring coastal defence $[63,64]$. Restoration can take a variety of forms as described in [65], and in order to protect beaches, they must allow for wave breaking, friction and coral growth (as described in Section 3). Here, we consider coral gardening as the core of our solution.

Coral gardening - which refers to the out planting of corals after an intermediate nursery phase-is a vital component of any restoration response to coastal protection, as it seeks to directly increase hard coral cover. Gardening can occur either on its own as a fully green solution, or in combination with artificial substrate, as a gray-green or hybrid solution. The green solution refers to out-planting reared corals directly onto a coral reef, while the hybrid entails out-planting corals onto artificial reefs [47].

In order for these interventions to be effective with respect to coastal protection, survival and growth rates of reared coral are particularly important. Corals must withstand the rigors of transplantation and remain alive until at least sexual maturity in order to ensure long-term resilience. In one of the most extensive reviews on coral restoration to date [47], an average survival rate of $66 \%$ for restored corals, from an assessment of 363 case studies in 56 countries, was found. Many of these studies were short-term, i.e., 12 months, with only five extending to over a decade. The few long-term monitoring efforts recorded, indicate either high survival- $80 \%$ on average- or no difference in mortality between out-planted corals and those on control sites [66]. Restored corals must also grow high enough to break waves, and faster growing corals, such as Acropora spp.-with growth rates averaging 100-150 mm per year [37] —are already among the most common species used in restoration. Their suitability for the process is well documented [64]. They are also important as structural builders [67] and employ reproductive strategies adapted to the shallow, high-energy conditions in which they are often out-planted [68,69].

A case study carried out in Barbados [70] provides details of coral gardening and hybrid interventions as a means of promoting coastal protection (Table 1). In this study: i. reefs were assessed to determine if they provided coastal protection; ii. numerical models were used to demonstrate that restoring reef structure could improve the service; and iii. suitable restoration techniques were suggested and costed. Total costs were determined for an area of $360 \mathrm{sq} \mathrm{m}$. The size of the restoration was based on breakwaters constructed under similar conditions in Barbados and fell within the parameters suggested as suitable for restoration for coastal protection with these reef shapes [71].

The solutions can be scaled up if required for Caribbean reefs using Acropora spp; however, restoration for coastal protection is not solely a matter of size and a larger area therefore is not necessarily better. The size of the area to be restored will be determined by the solution chosen and site characteristics.

Coral gardening can therefore be summarized as a low cost, high-risk solution, with a relatively long time frame to medium effectiveness, while the hybrid is a high cost, low-risk solution with a relatively short time frame to high effectiveness.

Restoration is a relatively new field, but we believe there is adequate scientific certainty that when properly carried out and within a holistic system of reef management, it can be effective at increasing hard coral cover $[47,72]$, hence improving coastal protection. Further studies, such as [71], have demonstrated via numerical models, the size, shapes and locations on reefs, where restoration can be most effective at protecting beaches. 
Table 1. Summary of performance, timeframes, risk and costs (\$USD) for coral gardening and hybrid solutions, over $360 \mathrm{sq} \mathrm{m}$. from a case study carried out in Barbados.

\begin{tabular}{|c|c|c|}
\hline & Green Coral Gardening & $\begin{array}{l}\text { Gray-Green HybridArtificial Reef + } \\
\text { Coral Gardening }\end{array}$ \\
\hline $\begin{array}{l}\text { Functional performance-ability to } \\
\text { attenuate wave energy }\end{array}$ & $\begin{array}{l}\text { Medium-the ability of restored corals to } \\
\text { reach the required height for wave breaking } \\
\text { is not assured. Even if they succeed in } \\
\text { wave-breaking, they cannot replace the } \\
\text { ecological complexities of a natural reef, that } \\
\text { also aid in wave attenuation. }\end{array}$ & $\begin{array}{l}\text { High-artificial structures can } \\
\text { immediately provide the required } \\
\text { shallowness for wave breaking. They also } \\
\text { provide suitable substrates for natural } \\
\text { coral recruitment and planting } \\
\text { from gardening. }\end{array}$ \\
\hline Time to effectiveness & $\begin{array}{l}\text { Minimum } 10 \text { years-for corals to grow to } \\
\text { suitable heights for wave breaking. }\end{array}$ & $\begin{array}{l}\text { Immediate for wave attenuation } \\
\text { Minimum } 5 \text { years for corals to colonise } \\
\text { artificial substrate. }\end{array}$ \\
\hline Risk of project failure & $\begin{array}{l}\text { High-e.g. from hurricanes, } \\
\text { bleaching, disease }\end{array}$ & $\begin{array}{l}\text { Medium-even with full mortality, } \\
\text { artificial structures will still (i) effectively } \\
\text { act as breakwaters, reducing wave energy } \\
\text { (ii) provide substrate for coral } \\
\text { recruitment, thus conferring growth and } \\
\text { accretion benefits over time. }\end{array}$ \\
\hline $\begin{array}{l}\text { Costs-growing \& outplanting, design } \\
\text { \& permits, material, construction, } \\
\text { maintenance ( } 25 \text { years) }\end{array}$ & $\$ 50,000$ & $\$ 112,000$ \\
\hline
\end{tabular}

There is still a risk, as methods for coastal protection have not been extensively tested in the field, and reared corals are also susceptible to a plethora of other stressors (e.g., storm damage, coral bleaching, disease and eutrophication) that could result in high levels of mortality, especially in a changing climate [57]. However, with little hope of impact reversal and ecosystem recovery in the short term [73], new methods, even with their element of risk should be employed. This risk factor will however have implications for private investment.

\section{Funding Restoration of Coral Reefs for Coastal Protection}

$\mathrm{NbS}$ are not yet being heavily financed. Out of a cumulative investment of USD\$94 billion, from the Global Environment Facility, Green Climate Fund, Adaptation Fund and the International Climate Initiative, for example, only \$12 billion has been spent on NbS [74]. Additionally, $\mathrm{NbS}$ for coastal erosion seem almost perfectly positioned to take advantage of private investment and to unlock additional funding [32]. Coastal hoteliers rely heavily on beaches for their business as tourists rate beach fronts among their most important attributes [75]. The building blocks therefore exist for viable payment for ecosystem services models, where beneficiaries (hotels) would pay for improved beach protection from $\mathrm{NbS}$. Such mechanisms could also attract private investors seeking environmental and financial returns and providing the up-front capital investment to the hotels. Additional incentives for the hotels include the possibility of reducing premiums for business interruptions insurances due to beach loss. Preliminary reports indicate that the cost of NbS could be covered by these gains on insurance premiums [76].

However, there are significant challenges related to establishing such funding mechanisms, that include knowledge gaps, technical constraints and lack of track records of success. These issues affect all stakeholders: the private investors who provide funds; the coastal hoteliers who can access the funds; and the marine conservation practitioners who carry out the work and may or may not be responsible for accessing funds. Conservation practitioners are often unaware that private investment is an option, and even when they are introduced to the concept are often hesitant to access monies that require repayment [77]. Traditional private investors typically select low-risk projects with business models designed to provide the greatest returns on investments. Even those who fund 
environment projects tend to concentrate on sectors, such as energy, rather than on the marine environment [78]. Technical constraints include risks associated with uncertainties of success; minimum tickets for investors, which exceed the monies required; and a shortage of investment-ready projects [79].

The issues are not insurmountable. In terms of knowledge gaps, increasing the attractiveness of marine conservation projects to private investors and of private investment to marine conservation practitioners entails improved communication and understanding of needs between two parties with historically divergent views towards money. For the technical constraints, financing strategies exist to minimize risk, such as de-risking instruments provided by development banks. At the same time, innovations in ecological engineering, for example, are increasing to reduce functional risks. With such challenges addressed, the foundation is created for projects that are ready for investment.

In Section 6, we briefly consider two private financing mechanisms for coastal hoteliers, that respond to some of the technical challenges identified.

\section{Private Financing Mechanisms for Coral Restoration}

Coastal hoteliers can access traditional debt finance from commercial banks for the more commonly utilized gray infrastructure to protect their beaches. This type of loan instrument, aimed at generating the highest returns with the lowest risk, is not suitable for restoration-like projects, with fledgling track records of success and ecological engineering uncertainties [80]. Payments for ecosystem service (PES) and impact investment, however, are both financing mechanisms with goals of generating positive impact, that can accommodate various levels of risk, but with very different requirements.

PES is a tool for managing ecosystems by providing incentives for behavioral changes. The system relies on beneficiaries of an ecosystem service making payments to providers of the service, which are conditional on specific targets or environmental action [81]. A review on the suitability of PES as a means of providing finance for coastal protection [82] concluded that PES would be most useful for a toolbox of coral reef conservation action within a marine protected area (MPA) framework. Such action is expected to improve the flow of a bundle of ecosystem services, including coastal protection, by improving coral reef health. Coastal hoteliers, as beneficiaries of coastal protection, could for example, make payments to MPA managers for providing the coral reef ecosystem service of protecting their beachfront. Specific targets - an intrinsic part of a PES mechanism-could include general improvements to coral health and/or restoration aimed at increasing cover of structural builders (Figure 1).

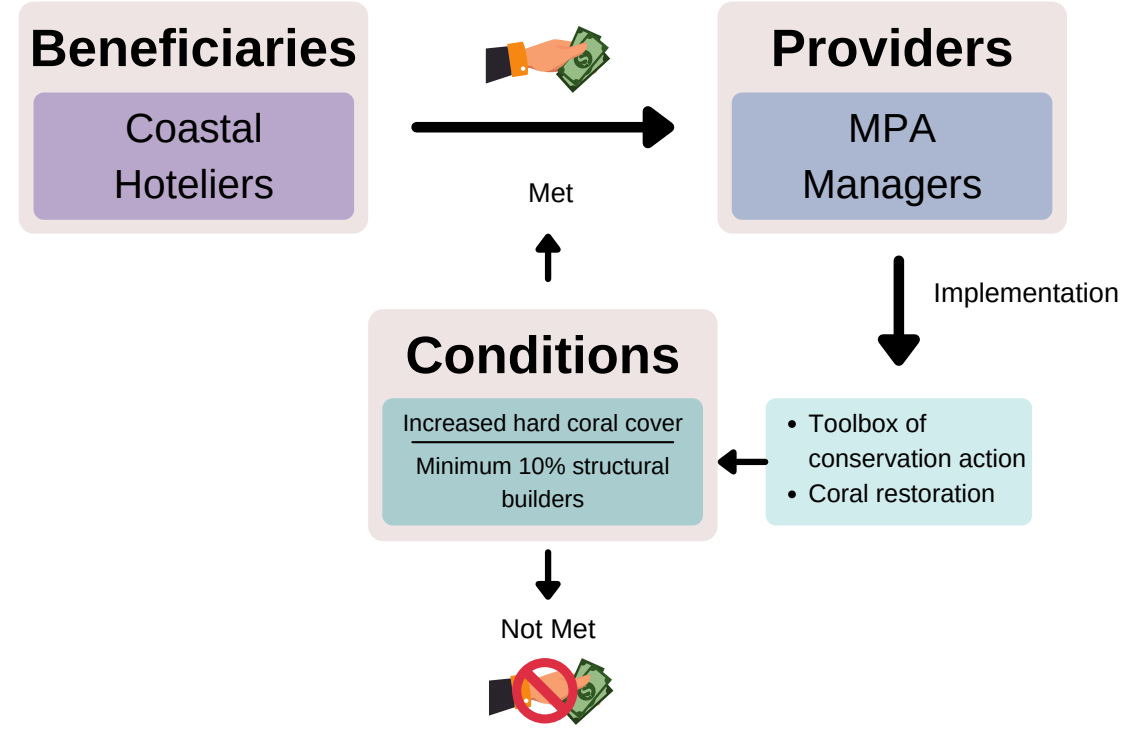

Figure 1. Potential PES mechanism to improve coastal protection. 
Impact investments are made in order to generate positive and measurable environmental, social and financial impacts [83]. This is a relatively new type of endeavor where investors are willing to accept lower financial expectations in exchange for having greater environmental or social impact. However, returns are required and, in the case of impact investment in debt, the borrower must repay the capital and interest over time [84]. These returns are dependent on investor goals and can be greater or less than the market price.

There is available money, as evidenced by the market size of impact investments, which averaged \$USD715 billion in 2020 [78]. Even with good intentions and available funding, however, impact investment has not succeeded in addressing many critical environmental needs, primarily as a result of "inflexible expectations for financial returns" [85].

Catalytic capital is defined as capital that allows for inordinate risk and/or sacrifices some financial gain for social benefits [86]. It can be in the form of grants and/or a derisking instrument, such as a loan guarantee for the impact investor from a development bank. Catalytic monies are therefore more patient and flexible than those from solely impact investment.

Combining impact investments with catalytic capital allows for investments more suited towards emerging technologies, such as coral restoration. This merging of capital with different risk levels, in order to meet the objectives of all, is called blended finance [87] and has been recommended as a means of financing $\mathrm{NbS}$ [80]. Blended finance solutions are complicated to develop and expensive [79]. Transaction costs, for example to ensure investment readiness can be high and there is a minimum investment requirement for impact investors, below which they will not invest.

For coastal protection, the blended finance funds can be accessed by either the hotelier or the marine conservation practitioner that is responsible for implementing the project. A potential blended finance scheme with a hotelier as the entity requesting funds is outlined in Figure 2.

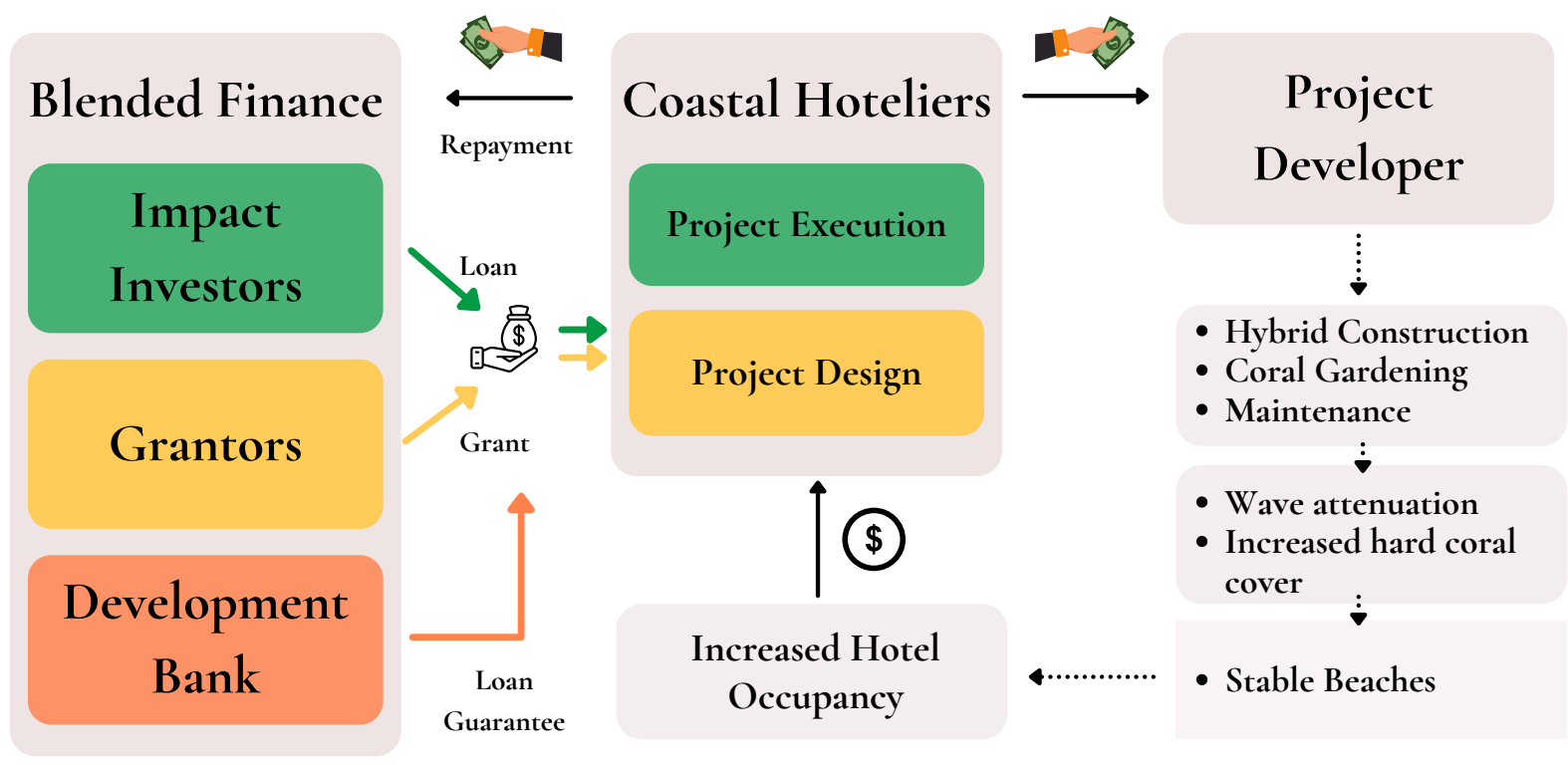

Figure 2. Potential blended finance investment model, with coastal hoteliers as recipients of funds.

Coral gardening with its low up-front cost and long timeframe to effectiveness is especially well suited to PES, once coastal erosion is not an immediate issue. As a direct ongoing, engagement between the hotelier and MPA practitioner, coral health can potentially be gradually improved over time, from a hotel's budget, without a need for external investment, and the stress of having to make financial returns. Environmental (and social) returns can be achieved from complementary coral reef ecosystem services, such as recreational and aesthetic. Thus, benefits can be achieved during the time that corals take to become effective at attenuating waves for coastal protection. This type of arrangement 
would only be feasible in cases with stable beaches, where hoteliers have time to make calm decisions for the future.

The hybrid NbS solution with its high up-front investment cost and relatively short time frame to high effectiveness is more suited to blended finance. In this case, the hotelier or the marine conservation practitioner would interact with external investors, who require financial and environmental returns on investment, within specific timeframes. The higher upfront costs will be more attractive to impact investors, coupled with a reduction in both engineering risk and timeframe, due to the presence of the artificial reef, that immediately allows for wave breakage and beach protection. At the same time, the financial risk linked to the $\mathrm{NbS}$ performance could be reduced by a loan guarantee from a development bank to the impact investors.

It should be noted that for both financing mechanisms, the details have been greatly simplified to demonstrate what is possible. There are many other steps and agreements required prior to implementation [79].

\section{Conclusions and Recommendations}

With a financing gap of $\$ 598$ to $\$ 824$ billion identified for biodiversity [88], it is imperative that monetary solutions are found. The situation is especially dire for coral reefs, which are on the brink of collapse [26]. There is little time remaining to seek greater certainty for restoration; therefore, while there are still many questions to be answered, and hence risk in terms of investment, inertia is not the most judicious course of action.

The private sector's inclusion in the world of coral reef conservation is a natural fit, as these ecosystems not only protect the investments of coastal hoteliers, but have additional income earning potential related to their aesthetics. Encouraging coastal hoteliers to invest in the protection of coral reefs that contribute to stable beaches should not be a difficult endeavor. Both high and low-risk NbS interventions and high and low costs can be accommodated, with different private sector financing mechanisms.

One of the serious challenges for coral restoration, is scaling up [47]. However, for private investment in coastal protection, one can work at the scale of one reef to protect a specific beach for coastal hoteliers who are willing to invest in their own solution. Such smaller scale solutions are also important for inter alia trialing new technologies and promoting tourism economies [72].

We recommend the following as means of encouraging private investment in coral restoration.

Recommendation 1: Improve the visibility of private investors to conservation practitioners, as well as communication between both parties.

With one primary hindrance being a lack of knowledge of opportunities available with private investment, solutions revolve around information transfer. The idea of economy and ecology being mutually beneficial is not a new concept, but it is taking time to gain traction. Initial ideas emerged in the 1970s and have continued to evolve to the current concept of a triple bottom line of improving economic, environmental and social targets $[79,89,90]$. On this trajectory, the inclusion of private sector investment in conservation is expected to increase. Sharing information on private investment opportunities for conservation can be accomplished in physical spaces, such as the Finance Pavilion of the 2021 IUCN World Conservation Congress, and online events, e.g., the Next Normal Now series organized by the Global Impact Investing Network, aimed at conservation practitioners.

Recommendation 2: Provide evidence of the ability of coral restoration to positively impact coastal protection.

Research Institutions and NGOs must start providing robust evidence of the ability of coral restoration to aid in coastal defence, and the costs to do so. Such outputs will contribute to a greater increase in private investor confidence. At present, numerical models have demonstrated that enhancing reefs can improve coastal protection [71,91], while restoration practitioners are increasingly improving their methods, success rates and reporting [47]. What is now required is implementation of coral restoration for coastal 
defence, in a variety of scenarios and documentation of the outputs-both successes and failures.

Recommendation 3: Improve the attractiveness of NbS to private investors.

Governments can play key roles in incentivizing private investment in restoration. While direct funding is often limited, government subventions will remain important, with seas being common resources and for the benefit of all [28]. Further, public entities can play enormously important roles in catalyzing the flow of funds from the private sector to conservation organizations via incentives, appropriate regulatory environments and market structures. In addition, the provision of pre-hazard mitigation funding, such as the grants provided by the Federal Emergency Management Agency (FEMA) in the United States of America, can also assist in reducing the overall cost of restoration efforts.

While conservation projects, especially marine ecosystems, are not strongly attracting impact capital from investors, this is slowly changing with NGOs, such as Blue finance (www.blue-finance.org, accessed on 5 January 2022) for example structuring blended finance solutions for the MPAs under its purview.

It is unlikely that the benefits of assisting coral reef recovery and enhanced protection are larger than the cost of doing nothing [92]. The dearth of information on successes and failures of NbS has impeded investment opportunities [79]. However, with scientific evidence and numerical models strongly suggesting the likelihood of restoration succeeding at improving coastal protection, coupled with more flexible financing aimed at positive impact, "the stage is set" for private investment.

The years 2021-2030 have been designated the UN Decade on Ecosystem Restoration. It is a good opportunity, with a global focus on restoration, to highlight private investment as means of financing this type of intervention. Practitioners in the conservation and investment fields must learn and understand each other's worlds so that this emerging source of funding can be effectively engaged and deployed.

Author Contributions: Conceptualization, A.B. and E.C.; data curation, N.P. and A.B.; original draft preparation, A.B.; writing, A.B.; review and editing, N.P.; visualization, A.B.; supervision, E.C.; funding acquisition, N.P. All authors have read and agreed to the published version of the manuscript.

Funding: This research received no external funding.

Institutional Review Board Statement: Not applicable.

Informed Consent Statement: Not applicable.

Data Availability Statement: Not applicable.

Conflicts of Interest: The authors declare no conflict of interest.

\section{References}

1. Forbes, D.L.; James, T.S.; Sutherland, M.; Nichols, S.E. Physical basis of coastal adaptation on tropical small islands. Sustain. Sci. 2013, 8, 327-344. [CrossRef]

2. IPCC. Climate Change 2014: Synthesis Report. Contribution of Working Groups I, II and III to the Fifth Assessment Report of the Intergovernmental Panel on Climate Change; IPCC: Geneva, Switzerland, 2014; p. 151.

3. Nurse, L.A.; McLean, R.F.; Agard, J.; Briguglio, L.P.; Duvat-Magnan, V.; Pelesikoti, N.; Tompkins, E.; Webb, A. Small Islands; Cambridge University Press: Cambridge, UK; New York, NY, USA, 2014; pp. 1613-1654.

4. Ferrario, F.; Beck, M.W.; Storlazzi, C.D.; Micheli, F.; Shepard, C.C.; Airoldi, L. The effectiveness of coral reefs for coastal hazard risk reduction and adaptation. Nat. Commun. 2014, 5, 3794. [CrossRef] [PubMed]

5. Kushner, B.; Edwards, P.; Burke, L.; Cooper, E. Coastal Capital: Jamaica; World Resources Institute: Washington, DC, USA, 2011.

6. Principe, P.; Bradley, P.; Yee, S.H.; Fisher, W.S.; Johnson, E.; Allen, P.E.; Campbell, D.E. Quantifying Coral Reef Ecosystem Services; US Environmental Protection Agency, Office of Research and Development: Research Triangle Park, NC, USA, 2012.

7. Quataert, E.; Storlazzi, C.; Van Rooijen, A.; Cheriton, O.; Van Dongeren, A. The influence of coral reefs and climate change on wave-driven flooding of tropical coastlines. Geophys. Res. Lett. 2015, 42, 6407-6415. [CrossRef]

8. Beck, M.W.; Lange, G.M. Wealth Accounting. In Managing Coasts with Natural Solutions: Guidelines for Measuring and Valuing the Coastal Protection Services of Mangroves and Coral Reefs; The World Bank: Washington DC, USA, 2016; pp. 1-167.

9. Eliff, C.I.; Reimao, I.; Canovas, V.; Gonzles, M. Wave Attenuation and Shoreline Protection by a Fringing Reef System. Anu. Do Inst. Geocienc. 2019, 42, 87-94. [CrossRef] 
10. Yao, Y.; Zhang, Q.; Chen, S.; Tang, Z. Effects of reef morphology variations on wave processes over fringing reefs. Appl. Ocean Res. 2019, 82, 52-62. [CrossRef]

11. Monismith, S.G.; Rogers, J.S.; Koweek, D.; Dunbar, R.B. Frictional wave dissipation on a remarkably rough reef. Geophys. Res. Lett. 2015, 42, 4063-4071. [CrossRef]

12. Reguero, B.G.; Beck, M.W.; Agostini, V.N.; Kramer, P.; Hancock, B. Coral reefs for coastal protection: A new methodological approach and engineering case study in Grenada. J. Environ. Manag. 2018, 210, 146-161. [CrossRef]

13. Sheppard, C.; Dixon, D.J.; Gourlay, M.; Sheppard, A.; Payet, R. Coral mortality increases wave energy reaching shores protected by reef flats: Examples from the Seychelles. Estuar. Coast. Shelf Sci. 2005, 64, 223-234. [CrossRef]

14. van Zanten, B.T.; van Beukering, P.J.; Wagtendonk, A.J. Coastal protection by coral reefs: A framework for spatial assessment and economic valuation. Ocean Coast. Manag. 2014, 96, 94-103. [CrossRef]

15. Hoegh-Guldberg, O.; Mumby, P.J.; Hooten, A.J.; Steneck, R.S.; Greenfield, P.; Gomez, E.; Harvell, C.D.; Sale, P.F.; Edwards, A.J.; Caldeira, K. Coral reefs under rapid climate change and ocean acidification. Science 2007, 318, 1737-1742. [CrossRef]

16. Mumby, P.J.; Flower, J.; Chollett, I.; Box, S.J.; Bozec, Y.-M.; Fitzsimmons, C.; Forster, J.; Gill, D.; Griffith-Mumby, R.; Oxenford, H.A.; et al. Towards Reef Resilience and Sustainable Livelihoods: A Handbook for Caribbean Coral Reef Managers; University of Exeter: Exeter, UK, 2014.

17. Vercelloni, J.; Liquet, B.; Kennedy, E.V.; González-Rivero, M.; Caley, M.J.; Peterson, E.E.; Puotinen, M.; Hoegh-Guldberg, O.; Mengersen, K. Forecasting intensifying disturbance effects on coral reefs. Glob. Chang. Biol. 2020, 26, 2785-2797. [CrossRef] [PubMed]

18. Bindoff, N.L.; Cheung, W.W.; Kairo, J.G.; Arístegui, J.; Guinder, V.A.; Hallberg, R.; Hilmi, N.J.M.; Jiao, N.; Karim, M.S.; Levin, L. Changing Ocean, Marine Ecosystems, and Dependent Communities; IPCC: Geneva, Switzerland, 2019; pp. 477-587.

19. Gardner, T.A.; Côté, I.M.; Gill, J.A.; Grant, A.; Watkinson, A.R. Long-Term region-wide declines in Caribbean corals. Science 2003, 301, 958-960. [CrossRef] [PubMed]

20. Spalding, M.; Longley-Wood, K.; Acosta-Morel, M.; Cole, A.; Wood, S.; Haberland, C.; FerdaÒa, Z. Estimating Reef-Adjacent Tourism Value in the Caribbean. Available online: https://oceanwealth.org/wp-content/uploads/2019/02/Reef-AdjacentTourism-Value-Caribbean-Study.pdf (accessed on 8 June 2021).

21. Storlazzi, C.D.; Reguero, B.G.; Cole, A.D.; Lowe, E.; Shope, J.B.; Gibbs, A.E.; Nickel, B.A.; McCall, R.T.; van Dongeren, A.R.; Beck, M.W. Rigorously Valuing the Role of US Coral Reefs in Coastal Hazard Risk Reduction. 2019. Available online: https: / / pubs.usgs.gov / of /2019/1027 / ofr20191027.pdf (accessed on 15 June 2021).

22. Maiolo, M.; Mel, R.A.; Sinopoli, S. A Simplified Method for an Evaluation of the Effect of Submerged Breakwaters on Wave Damping: The Case Study of Calabaia Beach. J. Mar. Sci. Eng. 2020, 8, 510. [CrossRef]

23. Ahmadian, A. Numerical Models for Submerged Breakwaters: Coastal Hydrodynamics and Morphodynamics; Elsevier: Oxford, UK, 2016; p. 345.

24. Fabian, R.M.; Beck, W.; Potts, D.C. Reef Restoration for Coastal Defense: A Review; University of California Santa Cruz: Santa Cruz, CA, USA, 2013; p. 59.

25. Temmerman, S.; Meire, P.; Bouma, T.J.; Herman, P.M.; Ysebaert, T.; De Vriend, H.J. Ecosystem-Based coastal defence in the face of global change. Nature 2013, 504, 79-83. [CrossRef] [PubMed]

26. Kleypas, J.; Allemand, D.; Anthony, K.; Baker, A.C.; Beck, M.W.; Hale, L.Z.; Hilmi, N.; Hoegh-Guldberg, O.; Hughes, T.; Kaufman, L.; et al. Designing a blueprint for coral reef survival. Biol. Conserv. 2021, 257, 109107. [CrossRef]

27. OECD. A Comprehensive Overview of Global Biodiversity Finance. Available online: https://www.oecd.org/environment/ resources/biodiversity/report-a-comprehensive-overview-of-global-biodiversity-finance.pdf (accessed on 3 July 2021).

28. Bos, M.; Pressey, R.L.; Stoeckl, N. Marine conservation finance: The need for and scope of an emerging field. Ocean Coast. Manag. 2015, 114, 116-128. [CrossRef]

29. Beck, M.W.; Losada, I.J.; Menéndez, P.; Reguero, B.G.; Díaz-Simal, P.; Fernández, F. The global flood protection savings provided by coral reefs. Nat. Commun. 2018, 9, 2186. [CrossRef]

30. Pascal, N. Coral Reef Ecosystem Services Economic Valuation Experiences from The South Pacific. Ph.D. Thesis, Universitat Politeècnica de Catalunya Barcelona, Barcelona, Spain, 2013.

31. Pascal, N.; Allenbach, M.; Brathwaite, A.; Burke, L.; Le Port, G.; Clua, E. Economic valuation of coral reef ecosystem service of coastal protection: A pragmatic approach. Ecosyst. Serv. 2016, 21, 72-80. [CrossRef]

32. Banerjee, O.; Boyle, K.; Rogers, C.T.; Cumberbatch, J.; Kanninen, B.; Lemay, M.; Schling, M. Estimating benefits of investing in resilience of coastal infrastructure in small island developing states: An application to Barbados. Mar. Policy 2018, 90, 78-87. [CrossRef]

33. Hallegatte, S.; Green, C.; Nicholls, R.J.; Corfee-Morlot, J. Future flood losses in major coastal cities. Nat. Clim. Chang. 2013, 3, 802-806. [CrossRef]

34. Costa, M.B.; Araújo, M.; Araújo, T.C.; Siegle, E. Influence of reef geometry on wave attenuation on a Brazilian coral reef. Geomorphology 2016, 253, 318-327. [CrossRef]

35. Koch, E.W.; Barbier, E.B.; Silliman, B.R.; Reed, D.J.; Perillo, G.M.; Hacker, S.D.; Granek, E.F.; Primavera, J.H.; Muthiga, N.; Polasky, S. Non-linearity in ecosystem services: Temporal and spatial variability in coastal protection. Front. Ecol. Environ. 2009, 7, 29-37. [CrossRef] 
36. Tegart, W.; Sheldon, G.; Griffiths, D. The IPCC Impacts Assessment: Report Prepared for IPCC by Working Group II. Canberra; Australian Government Publishing Service: Canberra, Australia, 1990.

37. Dullo, W.-C. Coral growth and reef growth: A brief review. Facies 2005, 51, 33-48. [CrossRef]

38. Anthony, K. Coral reefs under climate change and ocean acidification: Challenges and opportunities for management and policy. Annu. Rev. Environ. Resour. 2016, 41, 59-81. [CrossRef]

39. Baldock, T.E.; Golshani, A.; Callaghan, D.P.; Saunders, M.I.; Mumby, P.J. Impact of sea-level rise and coral mortality on the wave dynamics and wave forces on barrier reefs. Mar. Pollut. Bull. 2014, 83, 155-164. [CrossRef]

40. Nauels, A.; Gütschow, J.; Mengel, M.; Meinshausen, M.; Clark, P.U.; Schleussner, C.-F. Attributing long-term sea-level rise to Paris Agreement emission pledges. Proc. Natl. Acad. Sci. USA 2019, 116, 23487-23492. [CrossRef]

41. Jackson, J.; Donovan, M.; Cramer, K.; Lam, V. Status and Trends of Caribbean Coral Reefs: 1970-2012. 2014. Available online: https:/ / www.researchgate.net/publication/264157662_Status_and_Trends_of_Caribbean_Coral_Reefs_1970-2012 (accessed on 3 July 2021).

42. Connell, J.H. Disturbance and recovery of coral assemblages. Coral Reefs 1997, 16, S101-S113. [CrossRef]

43. Linares, C.; Pratchett, M.; Coker, D. Recolonisation of Acropora hyacinthus following climate-induced coral bleaching on the Great Barrier Reef. Mar. Ecol. Prog. Ser. 2011, 438, 97-104. [CrossRef]

44. Osborne, K.; Thompson, A.A.; Cheal, A.J.; Emslie, M.J.; Johns, K.A.; Jonker, M.J.; Logan, M.; Miller, I.R.; Sweatman, H.P. Delayed coral recovery in a warming ocean. Glob. Chang. Biol. 2017, 23, 3869-3881. [CrossRef]

45. McWilliam, M.; Pratchett, M.S.; Hoogenboom, M.O.; Hughes, T.P. Deficits in functional trait diversity following recovery on coral reefs. Proc. R. Soc. B 2020, 287, 20192628. [CrossRef]

46. Montefalcone, M.; Morri, C.; Bianchi, C.N. Long-term change in bioconstruction potential of Maldivian coral reefs following extreme climate anomalies. Glob. Chang. Biol. 2018, 24, 5629-5641. [CrossRef] [PubMed]

47. Boström-Einarsson, L.; Babcock, R.C.; Bayraktarov, E.; Ceccarelli, D.; Cook, N.; Ferse, S.C.; Hancock, B.; Harrison, P.; Hein, M.; Shaver, E. Coral restoration-A systematic review of current methods, successes, failures and future directions. PLoS ONE 2020, 15, e0226631. [CrossRef] [PubMed]

48. Bellwood, D.R.; Pratchett, M.S.; Morrison, T.H.; Gurney, G.G.; Hughes, T.P.; Álvarez-Romero, J.G.; Day, J.C.; Grantham, R.; Grech, A.; Hoey, A.S. Coral reef conservation in the Anthropocene: Confronting spatial mismatches and prioritizing functions. Biol. Conserv. 2019, 236, 604-615. [CrossRef]

49. BBOP. The Mitigation Hierarchy. Available online: https://www.forest-trends.org/bbop/bbop-key-concepts/mitigationhierarchy/ (accessed on 15 December 2021).

50. Bradshaw, A.D. Underlying principles of restoration. Can. J. Fish. Aquat. Sci. 1996, 53, 3-9. [CrossRef]

51. Rau, G.H.; McLeod, E.L.; Hoegh-Guldberg, O. The need for new ocean conservation strategies in a high-carbon dioxide world. Nat. Clim. Chang. 2012, 2, 720-724. [CrossRef]

52. Rinkevich, B. Management of coral reefs: We have gone wrong when neglecting active reef restoration. Mar. Pollut. Bull. 2008, 56, 1821-1824. [CrossRef] [PubMed]

53. Bruno, J.F.; Côté, I.M.; Toth, L.T. Climate change, coral loss, and the curious case of the parrotfish paradigm: Why don't marine protected areas improve reef resilience? Annu. Rev. Mar. Sci. 2019, 11, 307-334. [CrossRef]

54. Rinkevich, B. The active reef restoration toolbox is a vehicle for coral resilience and adaptation in a changing world. J. Mar. Sci. Eng. 2019, 7, 201. [CrossRef]

55. De'ath, G.; Fabricius, K.E.; Sweatman, H.; Puotinen, M. The 27-year decline of coral cover on the Great Barrier Reef and its causes. Proc. Natl. Acad. Sci. USA 2012, 109, 17995-17999. [CrossRef]

56. Knowlton, N. Iconic coral reef degraded despite substantial protection. Proc. Natl. Acad. Sci. USA 2012, 109, 17734-17735. [CrossRef]

57. Mumby, P.J.; Steneck, R.S. Coral reef management and conservation in light of rapidly evolving ecological paradigms. Trends Ecol. Evol. 2008, 23, 555-563. [CrossRef] [PubMed]

58. Ortiz, J.C.; Pears, R.J.; Beeden, R.; Dryden, J.; Wolff, N.H.; Gomez Cabrera, M.D.C.; Mumby, P.J. Important ecosystem function, low redundancy and high vulnerability: The trifecta argument for protecting the Great Barrier Reef's tabular Acropora. Conserv. Lett. 2021, 14, e12817. [CrossRef]

59. Rinkevich, B. The Quandry of Active and Passive Reef Restoration in a Changing World. In Active Coral Restoration: Techniques for a Changing Planet; Vaughan, D., Ed.; J.D. Ross Publishing: Plantation, FL, USA, 2021.

60. Lirman, D.; Schopmeyer, S. Ecological solutions to reef degradation: Optimizing coral reef restoration in the Caribbean and Western Atlantic. PeerJ 2016, 4, 2597. [CrossRef] [PubMed]

61. Anthony, K.; Bay, L.K.; Costanza, R.; Firn, J.; Gunn, J.; Harrison, P.; Heyward, A.; Lundgren, P.; Mead, D.; Moore, T. New interventions are needed to save coral reefs. Nat. Ecol. Evol. 2017, 1, 1420-1422. [CrossRef] [PubMed]

62. Inácio, M.; Karnauskaitè, D.; Mikša, K.; Gomes, E.; Kalinauskas, M.; Pereira, P. Nature-based solutions to mitigate coastal floods and associated Socioecological impacts. In The Handbook of Environmental Chemistry; Springer: Berlin, Heidelberg, 2020.

63. Viehman, T.S.; Nemeth, M.; Groves, S.H.; Buckel, C.A.; Griffin, S.; Field, D.; Moore, T.D.; Moore, J. Coral assessment and restoration in the US Caribbean after 2017 hurricanes. NOAA Tech. Memo. NOS NCCOS 2020, 278. Available online: https:/ / coastalscience. noaa.gov/news / coral-assessment-and-restoration-results-released-for-u-s-caribbean-after-2017-hurricanes/ (accessed on 15 July 2021). 
64. Zepeda-Centeno, C.; Mariño-Tapia, I.; McLeod, E.; Rodríguez-Martínez, R.; Alvarez-Filip, L.; Banaszak, A.T.; Escudero-Castillo, M.; Silva-Casarín, R.; Mendoza-Baldwin, E.; Beck, M.; et al. Guidance Document for Reef Management and Restoration to Improve Coastal Protection: Recommendations for Global Applications based on Lessons Learned in Mexico; The Nature Conservancy: Mexico City, Mexico, 2018; p. 57.

65. Boström-Einarsson, L.; Ceccarelli, D.; Babcock, R.C.; Bayraktarov, E.; Cook, N.; Harrison, P.; Hein, M.; Shaver, E.; Smith, A.; Stewart-Sinclair, P.J.; et al. Reef Restoration and Adaptation Program: Current Practices. A report provided to the Australian Government by the Reef Restoration and Adaptation Program. 2019; p. 55. Available online: https://gbrrestoration.org/ resources/reports / (accessed on 15 July 2021).

66. Garrison, V.H.; Ward, G. Transplantation of storm-generated coral fragments to enhance Caribbean coral reefs: A successful method but not a solution. Rev. Biol. Trop. 2012, 60, 59-70. [CrossRef]

67. Graham, N.; Nash, K. The importance of structural complexity in coral reef ecosystems. Coral Reefs 2013, 32, 315-326. [CrossRef]

68. Boulon, R.; Chiappone, M.; Halley, R.; Jaap, W.; Keller, B.; Kruczynski, B.; Miller, M.; Rogers, C. Atlantic Acropora Status Review Document; Report to National Marine Fisheries Service, Southeast Regional Office: St. Petersburg, FL, USA, $2005 ;$ p. 152.

69. Roelfsema, C.; Kovacs, E.; Ortiz, J.C.; Wolff, N.H.; Callaghan, D.; Wettle, M.; Ronan, M.; Hamylton, S.M.; Mumby, P.J.; Phinn, S. Coral reef habitat mapping: A combination of object-based image analysis and ecological modelling. Remote Sens. Environ. 2018, 208, 27-41. [CrossRef]

70. Brathwaite, A.; Clua, E.; Pascal, N. Coral reef restoration for coastal protection: Crafting technical and financial solutions. J. Environ. Econ. Manag. 2021, Submitted. [CrossRef]

71. Roelvink, F.E.; Storlazzi, C.D.; van Dongeren, A.R.; Pearson, S.G. Coral Reef Restorations Can Be Optimized to Reduce Coastal Flooding Hazards. Front. Mar. Sci. 2021, 8. [CrossRef]

72. Hein, M.; McLeod, I.; Shaver, E.; Vardi, T.; Pioch, S.; Boström-Einarsson, L.; Ahmed, M.; Grimsditch, G. Coral Reef Restoration As a Strategy to Improve Ecosystem Services-A Guide to Coral Restoration Methods; United Nations Environment Program: Nairobi, Kenya, 2020.

73. IPCC. The Physical Science Basis. Contribution of Working Group I to the Sixth Assessment Report of the Intergovernmental Panel on Climate Change; Masson-Delmotte, V., Zhai, P., Pirani, A., Connors, S.L., Péan, C., Berger, S., Caud, N., Chen, Y., Goldfarb, L., Gomis, M.I., et al., Eds.; Cambridge University Press: Cambridge, UK, 2021; in press.

74. United Nations Environment Programme. Adaptation Gap Report 2020; UNEP: Nairobi, Kenya, 2021; p. 120.

75. Schuhmann, P.; Skeete, R.; Waite, R. The Economic Importance of Coastal and Marine Resources to Tourism in Barbados; University of N Caroline Wilmington and Caribbean Tourism Organisation: Wilmington, DE, USA, 2017.

76. Reguero, B.G.; Beck, M.W.; Schmid, D.; Stadtmüller, D.; Raepple, J.; Schüssele, S.; Pfliegner, K. Financing coastal resilience by combining nature-based risk reduction with insurance. Ecol. Econ. 2020, 169, 106487. [CrossRef]

77. CFA. Supporting Biodiversity Ventures: Assessing the Impact Investing Sector for an Investment Strategy to Support Environmental Entreprenuerism; Conservation Finance Alliance: New York, NY, USA, 2014; p. 34. Available online: https: / / static1.squarespace.com/static/57e1f17b37c58156a98f1ee4/t/5d13bc499993cf0001faf63c/1561574481958/Impact+Investing+ for+Biodiversity+Donlan+2014.pdf (accessed on 21 February 2021).

78. Hand, D.; Dithrich, H.; Sunderji, S.; Nova, N.; Global Impact Investing Network. Annual Impact Investor Survey. Available online: https:/ / thegiin.org/research/publication/impinv-survey-2020?gclid=Cj0KCQiA6NOPBhCPARIsAHAy2zAXIxH2N7 uRZJ5MsakihAHzOfKQxiSIUrs3oaBIrfVzUVGWM7vkh4kaAt0SEALw_wcB (accessed on 8 November 2021).

79. Pascal, N.; Brathwaite, A.; Bladon, A.; Claudet, J.; Clua, E. Impact investment in marine conservation. Ecosyst. Serv. 2021, $48,101248$. [CrossRef]

80. Thiele, T.; Alleng, G.; Biermann, A.; Corwin, E.; Crooks, S.; Fieldhouse, P.; Herr, D.; Matthews, N.; Roth, N.; Shrivastava, A.; et al. Blue Infrastructure Finance: A New Approach Integrating Nature-Based Solutions for Coastal Resilience; IUCN: Gland, Switzerland, 2020.

81. Bladon, A.J.; Short, K.M.; Mohammed, E.Y.; Milner-Gulland, E.J. Payments for ecosystem services in developing world fisheries. Fish Fish. 2016, 17, 839-859. [CrossRef]

82. Brathwaite, A.; Pascal, N.; Clua, E. When are payment for ecosystems services suitable for coral reef derived coastal protection?: A review of scientific requirements. Ecosyst. Serv. 2021, 49, 101261. [CrossRef]

83. Caseau, C.; Grolleau, G. Impact Investing: Killing Two Birds with One Stone? Financ. Anal. J. 2020, 76, 40-52. [CrossRef]

84. Hamrick, K. State of Private Investment in Conservation 2016. A Landscape Assessment of an Emerging Market. Available online: https:/ /www.forest-trends.org/wp-content/uploads/2017/03/2016SOPICReport_FINAL_Full-REV.pdf (accessed on 4 April 2021).

85. Koh, H. What Investors Need to Know to Embrace Catalytic Capital. Available online: https://ssir.org/articles/entry/what investors_need_to_know_to_embrace_catalytic_capital\# (accessed on 18 October 2021).

86. Leijonhufvud, C.; Locascio, B.; Pemberton, A.; Kaur, K. Catalytic Capital: Unlocking More Investment and Impact; Tideline: San Francisco, CA, USA, 2019. Available online: https://tideline.com/dev/published-research/catalytic-capital-unlockingmoreinvestment-and-imapact (accessed on 8 March 2021).

87. Taskforce, B.F.; Business and Sustainable Development Commission. Who is the Private Sector? Key Considerations for Mobilizing Institutional Capital Through Blended Finance. Working Paper. 2018. Available online: https://www.blendedfinance.earth/ working-papers-1/2018/4/12/who-is-the-private-sector-key-considerations-for-mobilising-institutional-capital-throughblended-finance (accessed on 18 November 2021). Working Paper. 
88. Deutz, A.; Heal, G.M.; Niu, R.; Swanson, E.; Townshend, T.; Zhu, L.; Delmar, A.; Meghji, A.; Sethi, S.A.; Tobin-de la Puente, J. Financing Nature: Closing the Global Biodiversity Financing Gap; The Paulson Institute, The Nature Conservancy, and the Cornell Atkinson Center for Sustainability: Chicago, IL, USA, 2020.

89. Huwyler, F.; Käppeli, J.; Serafimova, K.; Swanson, E.; Tobin, J. Conservation Finance: Moving beyond Donor Funding toward an Investor-Driven Approach; Credit Suisse, WWF, McKinsey\&Company: Zurich, Switzerland, 2014; p. 32.

90. Stubbs, W. Sustainable Entrepreneurship and B Corps. Bus. Strategy Environ. 2016, 26, 331-344. [CrossRef]

91. Harris, D.L.; Rovere, A.; Casella, E.; Power, H.; Canavesio, R.; Collin, A.; Pomeroy, A.; Webster, J.M.; Parravicini, V. Coral reef structural complexity provides important coastal protection from waves under rising sea levels. Sci. Adv. 2018, 4, 4350. [CrossRef]

92. Wong, P.P.; Losada, I.J.; Gattuso, J.-P.; Hinkel, J.; Khattabi, A.; McInnes, K.L.; Saito, Y.; Sallenger, A. Coastal systems and low-lying areas. Clim. Chang. 2014, 2104, 361-409. 